\title{
PERSEPSI PENGUNJUNG TERHADAP KENYAMANAN FASILITAS RUANG TERBUKA PUBLIK FORT ROTTERDAM
}

\author{
Ibrahim Tuahena ${ }^{* 1}$, Triyatni Martosenjoyo ${ }^{2}$, Abdul Mufti Radja ${ }^{3}$ \\ 1,2,3 Universitas Hasanuddin Makassar \\ e-mail: *1'Ibrahimtuahena@yahoo.com,2triyatni@unhas.ac.id,3muftiradja@yahoo.com
}

\begin{abstract}
Abstrak_Ruang terbuka publik sekitar Fort Rotterdam sering terlihat sepi dari pengunjung. Penelitian ini bertujuan untuk mengetahui persepsi pengunjung dan faktor yang mempengaruhi persepsi pengunjung terhadap kenyamanan fasilitas ruang terbuka publik Fort Rotterdam. Metode penelitian yang digunakan adalah metode kualitatif dengan analisis deskriptif. Variabel fasilitas yang diamati dalam penelitian diantaranya paving, tanaman, kios, tempat sampah, lampu, penanda, dan bangku. Variabel kenyamanan yang diamati adalah kenyamanan fisik yaitu kondisi fisik dan kajian antropometri pada fasilitas, kenyamanan psikospiritual yang dapat dicapai dengan adanya sarana untuk relaksasi, kenyamanan sosiokultural yaitu kenyamanan dalam interaksi sosial, dan kenyamanan lingkungan seperti aroma/bau-bauan, sirkulasi, daya alam, kebisingan, bentuk, keindahan, kebersihan, keamanan dan penerangan kawasan. Dalam penelitian digunakan kajian literatur untuk menganalisis variabel penelitian, dan menggunakan skala likert untuk menghitung hasil persepsi dari tiga puluh tiga responden yang dipilih secara acak. Penelitian dilakukan enam jam sehari pada hari sabtu, minggu, dan senin selama tiga bulan yakni bulan September sampai November 2018. Hasil penelitian menunjukan bahwa fasilitas pada ruang terbuka publik ini sudah nyaman karena dominan persepsi pengunjung adalah baik. Faktor pengaruh yang telah dikelompokan berdasarkan variabel kenyamanan diantaranya kenyamanan fisik yang belum baik, kenyamanan psikospiritual belum baik, kenyamanan sosiokultural sudah baik dan kenyamanan lingkungan yang sudah baik.
\end{abstract}

Kata kunci: Ruang Terbuka Publik; Fort Rotterdam; Kenyamanan; Fasilitas.

\begin{abstract}
Abstrak_Public open spaces around Fort Rotterdam often look deserted by visitors, This study aims to understand visitor perceptions and factors that influence visitors' perceptions of Fort Rotterdam's public comfort facilities. The research method used is a qualitative method with descriptive analysis. Facility variables invited in the study discussed paving, shade plants, kiosks, trash bins, lights, markers, and benches. The convenience variables discussed are physical comfort, namely physical studies and anthropometric studies on facilities, psychospiritual comfort that can be achieved by considering the comfort of air, plants, and good regional transportation, sociocultural comfort, namely comfort, social, and comfort such as aroma, circulation, climate, climate, security, security, regional lighting. In this study literature studies were used to analyze the research variables, then using the Likert scale to calculate the results of the evaluations of thirty-three respondents randomly selected. The study was conducted for six hours on Saturday, Sunday, and Monday for three months from September to November 2018. The results showed that Fort Rotterdam's public open space facilities were comfortable because the dominant perception of visitors was good. comfort factors that have been grouped based on comfort variables, namely physical comfort yet, psychospiritual comfort is not good, sociocultural comfort is good and environmental comfort is good.
\end{abstract}

Keywords: Public Open Space; Fort Rotterdam; Comfort; Facilities.

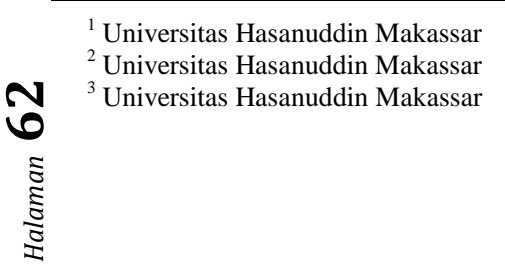




\begin{tabular}{r|l} 
Persepsi Pengunjung Terhadap Kenyamanan Fasilitas & Ibrahim Tuahena*, \\
Ruang Terbuka Publik Fort Rotterdam & Triyatni Martosenjoyo, \\
& Abdul Mufti Radja
\end{tabular}

\section{PENDAHULUAN}

Ruang terbuka publik bukan saja merupakan ruang luar yang bersifat sebagai perancangan lansekap untuk taman kota saja atau daerah hijau dalam kota tetapi lebih condong pada keterlibatan manusia didalamnya sebagai pengguna fasilitas tersebut (Wijayaningsih, 2007) Kemampuan manusia didalam memahami ruang yang diciptakan guna memenuhi kebutuhannya tersebut sangat tergantung dari bagaimana interaksi antara manusia dengan lingkungan binaan (yang diciptakan untuk kebutuhan manusia) dan bagaimana pengaruh ruang atau lingkungan tersebut terhadap persepsinya tentang kenyamanan (Wiharnanto, 2006). Konsep tentang kenyamanan (comfort) sangat sulit untuk didefinisikan karena lebih merupakan penilaian responsif individu (Zabdi, 2016). Penjelasan menurut SNI 03-1733-2004 kriteria kenyamanan adalah dicapai dengan kemudahan pencapaian (aksesibilitas), kemudahan berkomunikasi (internal/eksternal, langsung atau tidak langsung), kemudahan berkegiatan (prasarana dan sarana lingkungan tersedia).

Kawasan ruang terbuka publik Fort Rotterdam ini sering terlihat sepi pengunjung bahkan saat Benteng sedang ramai pengunjungnya (Hildayanti dan Wasilah 2017). Fasilitas yang tidak terawat, kolam taman yang sudah tidak berfungsi, kebersihan yang tidak terjaga, kurangnya tempat duduk, ruang terbuka tanpa pepohonan yang membuat pengunjung kepanasan menjadi alasan pengunjung merasa tidak nyaman (Santosa et al. 2018). Penelitian ini memiliki batasan pada wilayah penelitian yaitu bagian entrance Benteng yang terdiri atas pelataran parkir dan taman bunga, bagian sebelah kiri entrance yaitu kawasan yang teduh dan hijau dengan pepohonanan rimbun, serta kawasan sebelah kanan yaitu taman kota jalan W. R. Supratman.

\section{METODE}

Penelitian ini merupakan penelitian kualitatif dengan analisis deskriptif. Penelitian ini dilakukan selama bulan September hingga bulan November 2018. Waktu penelitian Sembilan hari dalam sebulan yaitu tiga hari di awal bulan (Sabtu, Minggu dan Senin), tiga hari pada pertengahan bulan (Sabtu, Minggu dan Senin), dan tiga hari di akhir bulan (Sabtu, Minggu dan Senin). Penelitian dilakukan enam jam dalam satu hari yaitu pukul 06.00-08.00 Pagi, pukul 12.00-13.00, pukul 16.0018.00 Sore yang merupakan waktu puncak kawasan, dimana saat ini lebih ramai pengunjung dibanding pagi dan siang hari serta untuk mengetahui pola perilaku pengunjung dan kondisi lingkungan kawasan saat berada pada waktu puncak, pukul 21.00-22.00. Penelitian ini dilakukan pada kawasan ruang terbuka publik sekitar Fort Rotterdam. Peta lokasi dan delineasi/batas lokasi penelitian ditunjukan pada gambar 1.

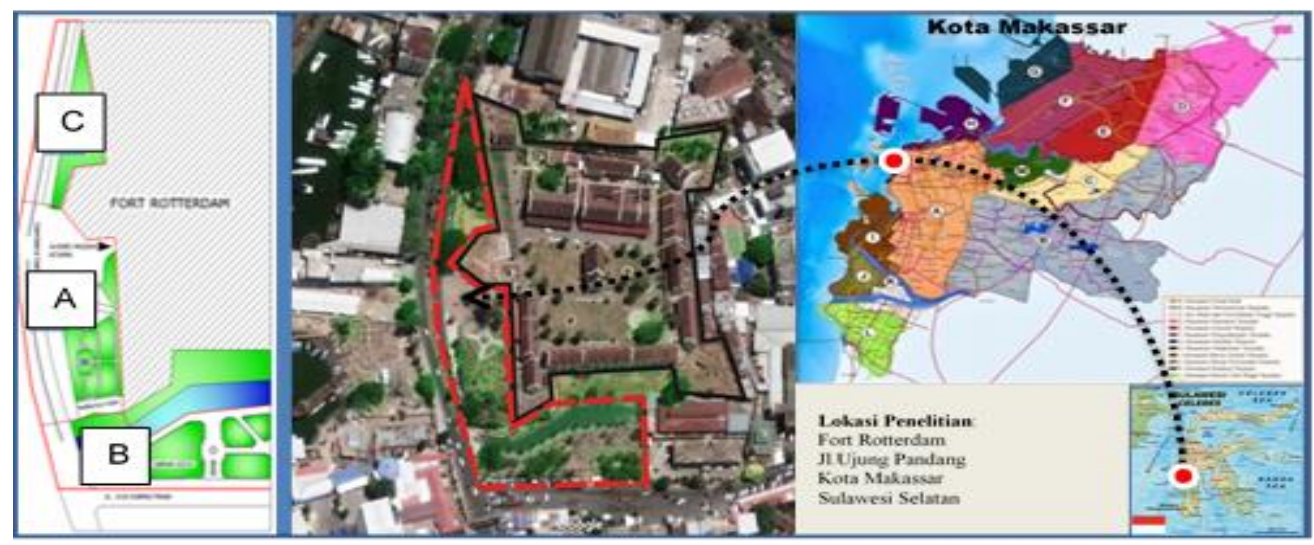

Gambar 1.Batas Lokasi Penelititan, Zona A. Entrance Kawasan Fort Rotterrdam, Zona B.Taman Kota, Zona C. Kawasan Hijau dengan Pepohonan Rimbun

Sumber: Google.com, Google Maps 
Ibrahim Tuahena

Triyatni Martosenjoyo

Abdul Mufti Radja

Variabel pengaruh (independent variabels) dari penelitan ini adalah fasilitas ruang terbuka publik yang telah tersedia diantaranya paving, tanaman peneduh, kios, tempat sampah, lampu, penanda, dan bangku. Variabel terpengaruh (dependent variebles) yaitu persepsi dan kenyamanan pengunjung, variabel kenyamanannya yaitu kenyamanan fisik, kenyamanan psikospiritual, kenyamanan sosiokultural dan kenyamanan lingkungan. Dalam penelitian digunakan kajian literatur sebagai acuan dalam menganalisis variabel penelitian, kemudian menggunakan skala likert untuk menghitung hasil persepsi dari 33 responden penelitian yang dipilih secara acak. Skala likert adalah skala pengukuran yang dikembangkan oleh Likert. Skala likert memiliki empat atau lebih butir-butir pertanyaan yang dikombinasikan sehingga membentuk sebuah skor atau nilai yang mempersentasikan sifat individu, misalnya pengetahuan, sikap dan perilaku. Dalam proses analisis data, komposit skor, biasanya jumlah dari semua butir pertanyaan yang dapat digunakan.

\section{HASIL DAN PEMBAHASAN}

\section{Kenyamanan Fasilitas Ruang Publik Fort Rotterdam}

Data hasil pengamatan dan persepsi dari pengunjung terhadap kenyamanan fasilitas ruang terbuka publik kawasan Fort Rotterdam dapat dilihat pada tabel 1 berikut.

Tabel 1.Kenyamanan Fasilitas Ruang Publik Fort Rotterdam

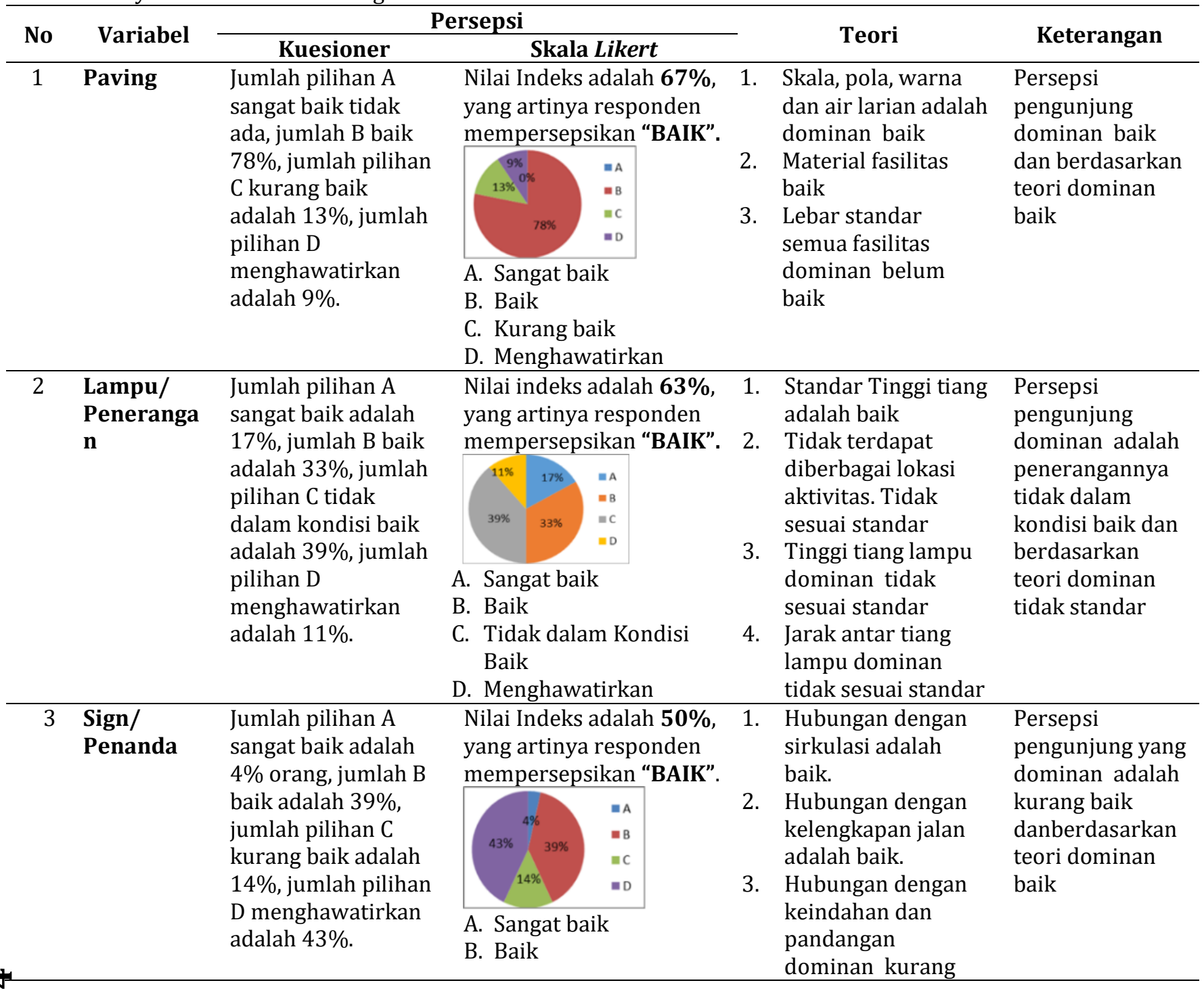


Ibrahim Tuahena*, Triyatni Martosenjoyo, Abdul Mufti Radja

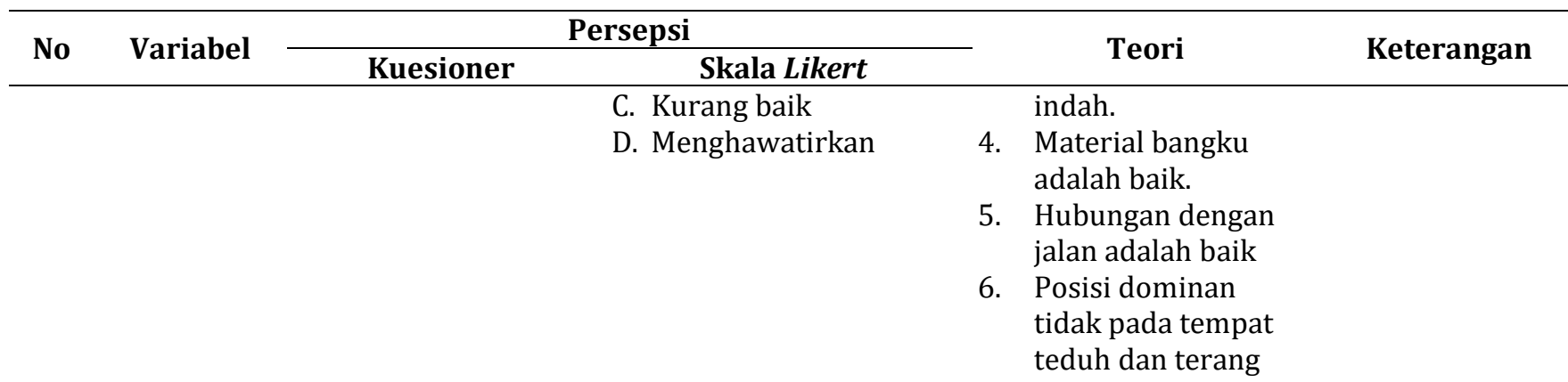

\begin{tabular}{|c|c|c|c|c|c|}
\hline 4 & Bangku & $\begin{array}{l}\text { Jumlah pilihan A } \\
\text { sangat baik adalah } \\
4 \% \text {, jumlah B baik } \\
\text { adalah 14\%, Jumlah } \\
\text { pilihan C kurang } \\
\text { baik adalah 50\%, } \\
\text { Jumlah pilihan D } \\
\text { menghatirkan } \\
\text { adalah 32\%. }\end{array}$ & 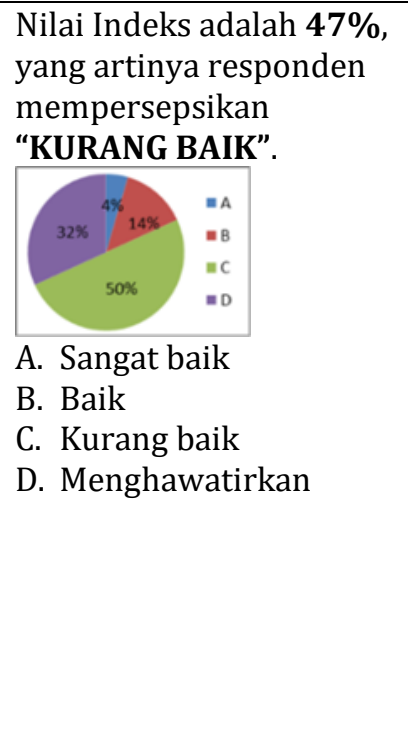 & $\begin{array}{l}\text { 1. Hubungan dengan } \\
\text { sirkulasi adalah } \\
\text { baik. } \\
\text { 2. } \begin{array}{l}\text { Hubungan dengan } \\
\text { kelengkapan jalan } \\
\text { adalah baik. }\end{array} \\
\text { 3. Hubungan dengan } \\
\text { keindahan dan } \\
\text { pandangan } \\
\text { dominan kurang } \\
\text { indah. } \\
\text { Material bangku } \\
\text { adalah baik. } \\
\text { 5ubungan dengan } \\
\text { jalan adalah baik } \\
\text { 6. Posisi dominan } \\
\text { tidak pada tempat } \\
\text { teduh dan terang }\end{array}$ & $\begin{array}{l}\text { Persepsi } \\
\text { pengunjung yang } \\
\text { dominan adalah } \\
\text { kurang baik } \\
\text { danberdasarkan } \\
\text { teori dominan } \\
\text { baik }\end{array}$ \\
\hline 5 & $\begin{array}{l}\text { Tanaman } \\
\text { Peneduh }\end{array}$ & $\begin{array}{l}\text { Jumlah pilihan A } \\
\text { sangat baik adalah } \\
12 \% \text {, jumlah B baik } \\
\text { adalah } 43 \% \text {, jumlah } \\
\text { pilihan C kurang } \\
\text { baik adalah 39\%, } \\
\text { jumlah pilihan D } \\
\text { menghawatirkan } \\
\text { adalah } 6 \% \text {. }\end{array}$ & 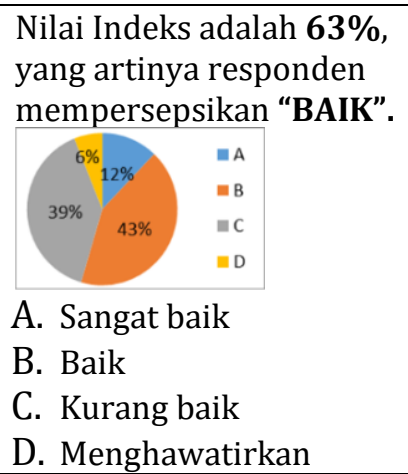 & $\begin{array}{ll}\text { 1. } & \text { Tahan cuaca } \\
\text { 2. } & \text { Bemassa daun } \\
\text { padat } \\
\text { 3. } \\
\text { 4. } \\
\text { Hubunis pohon. Baik } \\
\text { pedestrian. Baik } \\
\text { 5. } \\
\text { Ukuran dan } \\
\text { Hubungan dengan } \\
\text { perlengkapan jalan } \\
\text { adalah baik }\end{array}$ & $\begin{array}{l}\text { Persepsi } \\
\text { pengunjung } \\
\text { dominan baik } \\
\text { dan berdasarkan } \\
\text { teori juga } \\
\text { dominan baik }\end{array}$ \\
\hline 6 & $\begin{array}{l}\text { Kios/Shelt } \\
\text { er/Kanopi }\end{array}$ & $\begin{array}{l}\text { Jumlah pilihan A } \\
\text { adalah tidak ada, } \\
\text { jumlah B adalah } \\
53 \% \text {, jumlah pilihan } \\
\text { C adalah } 35 \% \text {, } \\
\text { jumlah pilihan D } \\
\text { adalah } 12 \% \text {. }\end{array}$ & 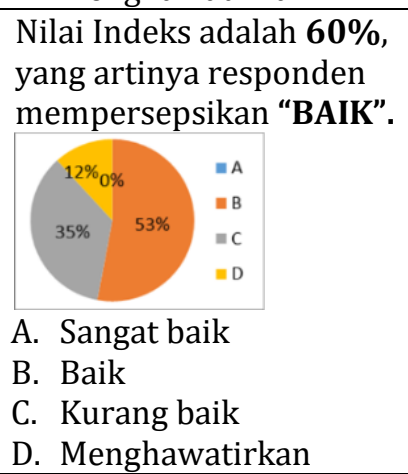 & $\begin{array}{l}\text { 1. Tidak maksimal } \\
\text { sebagai pelindung } \\
\text { dari cuaca } \\
\text { 2. Terdapat kanopi } \\
\text { untuk memperindah } \\
\text { wajah bangunan }\end{array}$ & $\begin{array}{l}\text { Persepsi } \\
\text { pengunjung } \\
\text { dominan baik } \\
\text { dan berdasarkan } \\
\text { teori dominan } \\
\text { kurang baik }\end{array}$ \\
\hline 7 & $\begin{array}{l}\text { Tempat } \\
\text { Sampah }\end{array}$ & $\begin{array}{l}\text { Jumlah pilihan A } \\
\text { sangat baik adalah } \\
\text { tidak ada, jumlah B } \\
\text { baik adalah 49\%, } \\
\text { jumlah pilihan C }\end{array}$ & $\begin{array}{l}\text { nilai Indeks adalah } \mathbf{5 7 \%}, \\
\text { yang artinya responden } \\
\text { mempersepsikan "BAIK". }\end{array}$ & $\begin{array}{l}\text { 1. Tempat sampah } \\
\text { telah terletak di } \\
\text { jalur pedestrian } \\
\text { dan berdampingan } \\
\text { dengan tempat }\end{array}$ & $\begin{array}{l}\text { Persepsi } \\
\text { pengunjung } \\
\text { dominan baik } \\
\text { dan berdasarkan } \\
\text { teori dominan }\end{array}$ \\
\hline
\end{tabular}




\section{Persepsi Pengunjung Terhadap Kenyamanan Fasilitas Ruang Terbuka Publik Fort Rotterdam

\author{
Ibrahim Tuahena \\ Triyatni Martosenjoyo \\ Abdul Mufti Radja
}

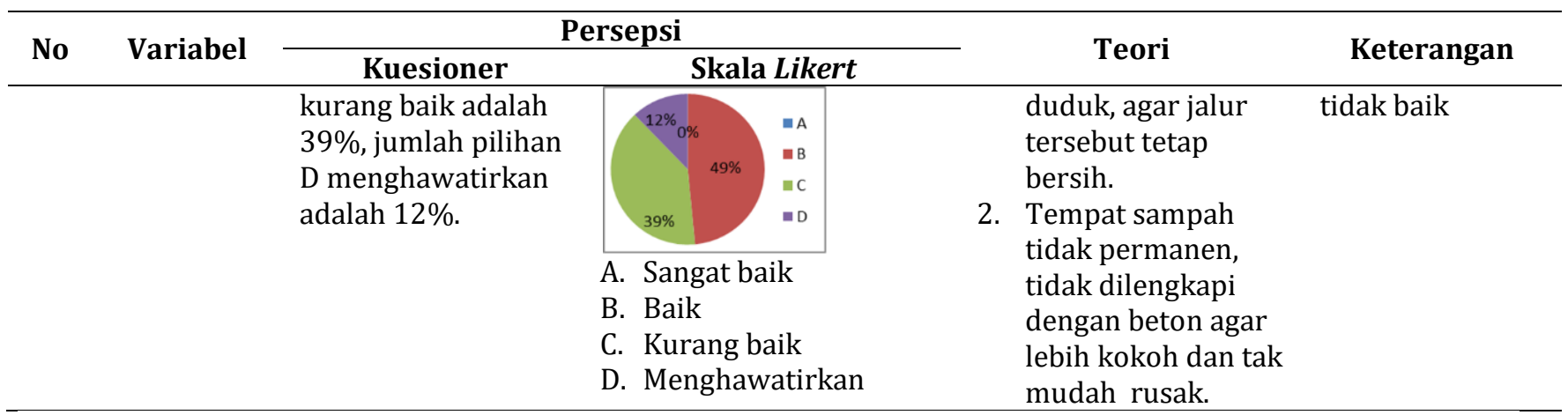

Sumber: Analisis Peneliti

\section{Faktor-Faktor yang Mempengaruhi Persepsi Pengunjung Terhadap Kenyamanan Fasilitas}

Faktor-faktor yang mempengaruhi persepsi pengunjung terhadap kenyamanan fasilitas ruang terbuka publik kawasan Fort Rotterdam berdasarkan kuesioner sebagai berikut:

\section{a. Kenyamanan Fisik}

Kondisi fisik ruang publik merupakan faktor eksternal yang mempengaruhi persepsi dari pengunjung, sehingga ruang publik yang nyaman seharusnya memenuhi beberapa indikator keberhasilan sebuah ruang publik. Kekuatan dan kelemahan ruang publik Fort Rotterdam ditinjau dari gambaran ruang publik menurut Whyte (1980) dapat dilihat pada tabel 2 berikut.

Tabel 2. Kondisi Fisik Kawasan Ruang Terbuka Publik Fort Rotterdam

\begin{tabular}{|c|c|c|c|}
\hline \multirow{2}{*}{ No } & \multirow{2}{*}{ Teori } & \multicolumn{2}{|c|}{ Kondisi Eksisting } \\
\hline & & Kekuatan & Kelemahan \\
\hline 1 & $\begin{array}{l}\text { Ruang terbuka yang baik } \\
\text { merupakan ruang yang } \\
\text { penuh dengan aktfitas } \\
\text { sosial serta menstimulasi } \\
\text { kreatifitas pengunjungnya. }\end{array}$ & $\begin{array}{l}\text { Aktivitas sosial seperti adanya } \\
\text { kegiatan dari pengunjung } \\
\text { dalam sebuah kelompok atau } \\
\text { komunitas yang terlihat } \\
\text { melakukan aktivitas bersama } \\
\text { pada kawasan ini. }\end{array}$ & $\begin{array}{l}\text { Tidak banyak kegiatan pengunjung } \\
\text { (yang berhubungan dengan } \\
\text { kreatifitas) yang terlihat melakukan } \\
\text { kegiatan bersama, bisa berarti } \\
\text { ruang publik ini masih belum } \\
\text { mampu menstimulasi kreatifitas } \\
\text { pengunjung. }\end{array}$ \\
\hline 2 & $\begin{array}{l}\text { Ruang terbuka yang baik } \\
\text { terdapat tempat untuk } \\
\text { duduk untuk mengajak } \\
\text { pengunjung ke dalam } \\
\text { ruang tersebut. }\end{array}$ & $\begin{array}{l}\text { Terdapat tempat duduk pada } \\
\text { kawasan ini, terbuat dari } \\
\text { material yang kuat seperti } \\
\text { beton, besi, dan kayu. }\end{array}$ & $\begin{array}{l}\text { Secara fisik masih kurang nyaman } \\
\text { untuk pengunjung karena tempat } \\
\text { duduk tidak berada pada semua } \\
\text { bagian kawasan, dan walau terbuat } \\
\text { dari bahan kuat namun banyak yang } \\
\text { rusak, tampilannya kurang menarik } \\
\text { sehingga berpengaruh pada } \\
\text { keindahan bentuknya, serta banyak } \\
\text { bangku yang terletak pada tempat } \\
\text { yang kurang teduh sehingga } \\
\text { berpengaruh pada kenyamanan } \\
\text { pengunjung. }\end{array}$ \\
\hline 3 & $\begin{array}{l}\text { Sinar matahari, angin, } \\
\text { pepohonan serta air } \\
\text { sebagai pertimbangan } \\
\text { dalam membentuk ruang } \\
\text { yang nyaman bagi } \\
\text { pengguna ruang publik. }\end{array}$ & $\begin{array}{l}\text { Terdapat kios berkanopi pada } \\
\text { kawasan ini serta pohon- } \\
\text { pohon teduh yang berfungsi } \\
\text { untuk melindungi pengunjung } \\
\text { dari pengaruh cuaca. }\end{array}$ & $\begin{array}{l}\text { Kondisi fisik Kios dan kanopi tidak } \\
\text { cukup untuk melindungi } \\
\text { pengunjung, pohon yang berfungsi } \\
\text { sebagai pelindung dari cuaca juga } \\
\text { kurang banyak sehingga kawasan } \\
\text { kurang teduh. }\end{array}$ \\
\hline 4 & $\begin{array}{l}\text { Kemudahan untuk } \\
\text { mengakses makanan di } \\
\text { ruang publik akan menarik }\end{array}$ & $\begin{array}{l}\text { Akses makanan selalu ada } \\
\text { karena banyak pedagang. }\end{array}$ & Tidak ada \\
\hline
\end{tabular}


Ibrahim Tuahena*, Triyatni Martosenjoyo, Abdul Mufti Radja

\begin{tabular}{|c|c|c|c|}
\hline \multirow{2}{*}{ No } & \multirow{2}{*}{ Teori } & \multicolumn{2}{|c|}{ Kondisi Eksisting } \\
\hline & & Kekuatan & Kelemahan \\
\hline & perhatian pengunjung. & & \\
\hline 5 & $\begin{array}{l}\text { Jalan dan ruang terbuka } \\
\text { publik memiliki hubungan } \\
\text { yang terintegrasi, dimana } \\
\text { satu sama lain saling } \\
\text { melengkapi. }\end{array}$ & $\begin{array}{l}\text { Semua pola jalan terhubung } \\
\text { pada seluruh kawasan. }\end{array}$ & Tidak ada \\
\hline 6 & $\begin{array}{l}\text { Orang yang dapat } \\
\text { mengurangi kualitas } \\
\text { kenyamanan ruang publik } \\
\text { dikarenakan } \\
\text { keberadaannya. }\end{array}$ & $\begin{array}{l}\text { Anak jalanan jarang terlihat } \\
\text { serta tidak ada orang yang } \\
\text { menjadikan ruang publik ini } \\
\text { sebagai tempat tinggal. }\end{array}$ & $\begin{array}{l}\text { Kadang terlihat banyak anak } \\
\text { jalanan yang mengganggu aktivitas } \\
\text { pegunjung pada hari-hari tertentu. }\end{array}$ \\
\hline 7 & $\begin{array}{l}\text { Kapasitas yang efektif } \\
\text { adalah jumlah orang yang } \\
\text { dengan bebas akan duduk } \\
\text { di tempatnya selama waktu } \\
\text { puncak normal. }\end{array}$ & $\begin{array}{l}\text { Waktu puncak biasanya pada } \\
\text { hari libur, banyak pengunjung } \\
\text { ditambah lagi bus pengunjung } \\
\text { yang juga banyak } \\
\text { bersatangan. Para pengunjung } \\
\text { bisa duduk dan bersantai. } \\
\text { Banyak dari mereka duduk } \\
\text { pada bangku yang dusediakan } \\
\text { oleh para pedagang, sebagian } \\
\text { lagi duduk pada paving taman, } \\
\text { trotoar, dan emperan taman. }\end{array}$ & $\begin{array}{l}\text { Fasilitas bangku taman tidak } \\
\text { tersedia pada seluruh kawasan. }\end{array}$ \\
\hline 8 & $\begin{array}{l}\text { Sesuatu yang dapat } \\
\text { menstimulasi komunikasi } \\
\text { antar orang per orang } \\
\text { dalam suatu komunitas, } \\
\text { biasanya berupa komentar } \\
\text { terhadap hal ketiga. }\end{array}$ & $\begin{array}{l}\text { Terdapat beberapa objek fisik } \\
\text { yang memicu komunikasi } \\
\text { diruang publik ini, yakni } \\
\text { keberadaan benteng } \\
\text { rotterdam, keberadaan taman } \\
\text { bunga pada zona A, serta } \\
\text { adanya icon baru pada zona B } \\
\text { yaitu gong raksasa. }\end{array}$ & Tidak ada \\
\hline
\end{tabular}

Sumber: Analisis Peneliti (2018)

Tabel tentang fisik dari ruang terbuka publik Fort Rotterdam ini mengahasilkan simpulan bahwa kawasan ini memiliki lebih banyak nilai kekuatan dibanding kelemahan untuk sebuah ruang publik. Nilai kekuatan yang dimaksud ada pada kemudahan untuk mengakses makanan, jalan dan ruang terbuka publik memiliki hubungan yang terintegrasi dimana satu sama lain saling melengkapi dan adanya sesuatu yang dapat menstimulasi komunikasi, karena berdasarkan pengamatan tidak ditemukan kelemahan dari ketiga poin tersebut.

Suatu ruang terbuka publik dikatakan berhasil jika dapat mewadahi aktivitas kontak/interaksi antar anggota masyarakat (teman, keluarga atau orang asing) dengan baik serta mewadahi aktivitas pasif yang sangat dipengaruhi oleh kondisi lingkungannya. Hasil analisis mengenai fasilitas untuk duduk dan berjalan pada ruang terbuka ini dapat dilihat pada tabel 3 berikut ini. 
Ibrahim Tuahena

Triyatni Martosenjoyo

Abdul Mufti Radja

Tabel 3. Ukuran Fasilitas untuk Duduk dan Berjalan

\begin{tabular}{|c|c|c|c|c|}
\hline No & Fasilitas & Ketentuan Ukuran & $\begin{array}{c}\text { Ukuran } \\
\text { Eksisting }\end{array}$ & Keterangan \\
\hline 1 & Jalan Taman & $\begin{array}{l}\text { Min. 1.2M untuk searah } \\
\text { Min. } 1.60 \text { untuk dua arah }\end{array}$ & $\begin{array}{l}0.9 \mathrm{M} \\
1.2 \mathrm{M} \\
2.8 \mathrm{M}\end{array}$ & $\begin{array}{l}\text { Tidak Standar } \\
\text { Standar Searah } \\
\text { Lebih lebar }\end{array}$ \\
\hline 2 & Bangku/ Tempat Duduk & $\begin{array}{l}\text { Panjang }=1.5 \mathrm{M} \\
\text { Lebar }=0.5 \mathrm{M} \\
\text { Tinggi }=0.4 \mathrm{M}\end{array}$ & $\begin{array}{l}\mathrm{p}=1.5 \mathrm{M} \\
\mathrm{l}=0.6 \mathrm{M} \\
\mathrm{t}=0.5 \mathrm{M}\end{array}$ & $\begin{array}{l}\text { Lebih lebar dan } \\
\text { lebih tinggi }\end{array}$ \\
\hline 3 & Jarak Antar Tempat Duduk & $10 \mathrm{M}$ & $14 \mathrm{M}$ & Lebih jauh \\
\hline
\end{tabular}

Sumber: Analisis Peneliti (2018)

Hasil analisis pada tabel 3 memberikan simpulan bahwa ukuran fasilitas untuk duduk dan berjalan dominan tidak mengikuti standar yang ditetapkan pada Peraturan Mentri Pekerjaan Umum NO: 03/PRT/M/2014, tentang pedoman perencanaan, penyediaan, dan pemanfaatan prasarana dan sarana jaringan pejalan kaki di kawasan perkotaan.

\section{b. Kenyamanan Psikospiritual}

Aktivitas yang erat hubungannya dengan kenyamanan psikologi adalah relaksasi (relaxation). Suasana relaksasi mudah dicapai jika badan dan pikiran dalam kondisi sehat dan senang. Kondisi ini dapat dibentuk dengan menghadirkan unsur-unsur alam pada ruang publik diantaranya:

1) Tanaman/pohon

Pada ruang publik terdapat berbagai jenis pohon yang rindang walaupun keberadaan pepohonan sekarang masih kurang banyak sebagai pelindung dari sinar matahari dan penyaring kebisingan dan debu.Kondisinya fisik pohonnya baik, rimbun. Serta tanamantanaman lain seperti tanaman perdu dan bunga-bunga sangat baik untuk keindahan taman.

2) Air dengan lokasi yang terpisah

Pada ruang publik ini terdapat kolam pada Zona A dan kanal buatan pada Zona B, namun kedua kondisinya kurang baik. Kondisi fisik kolam baik namun tidak terisi air. Alasan dari penjaga taman berdasarkan wawancara adalah keamanannya karena mempertimbangkan perilaku anak-anak yang sering bermain di dalam kolam sehingga kolamnya harus dikuras sampai kering. Selanjutnya kanal buatan, kondisi fisiknya baik namun kondisi airnya yang kurang baik, terlihat kotor dan kurang terawat.

3) Terhindar dari kebisingan dan hiruk pikuk kendaraan di sekelilingnya.

Suasana Rileks mudah dengan cara terhindar dari kebisingan kendaraan, pada zona A Kebisingan paling tinggi sehingga kurang cocok untuk relaksasi, pada zona B bisa digunakan untuk relaksasi karena bisa terhindar dari kebisingan kendaraan dengan adanya pohon-pohon pelindung.

\section{c. Kenyamanan Sosiokultural}

Ruang publik yang baik memberi ruang untuk terjadinya Intraksi sosial. Interaksi sosial yang terjadi pada ruang publik Fort Rotterdam bisa sering kita temui, setiap perkumpulan orang yang ingin melakukan kegiatan bersama terlihat menggunakan area pedestrian untuk kegiatan komunitas, dan menggunakan pelataran parkir sebagai tempat bazar dan berkumpul, hal ini dapat terjadi karena pada ruang publik Fort Rotterdam memberi ruang yang cukup untuk terjadinya interaksi sosial, hal ini dapat dilihat pada gambar 2 berikut. 


\begin{tabular}{r|l|}
\cline { 2 - 2 } Persepsi Pengunjung Terhadap Kenyamanan Fasilitas & Ibrahim Tuahena*, \\
Ruang Terbuka Publik Fort Rotterdam & Triyatni Martosenjoyo, \\
& Abdul Mufti Radja
\end{tabular}
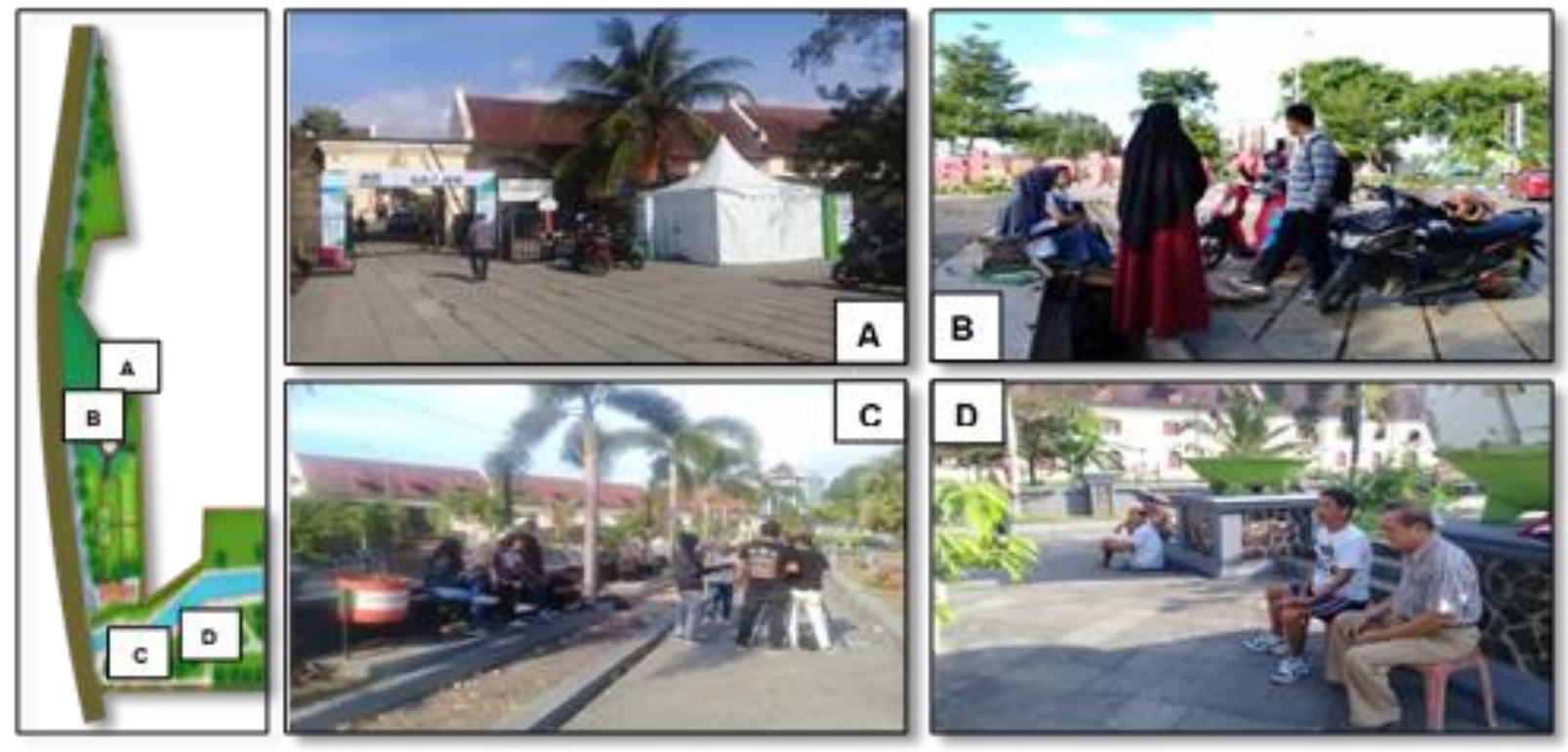

Gambar 2. Interaksi Sosial pada Ruang Terbuka Publik Fort Rotterdam Sumber: Dokumentasi (2018)

\section{d. Kenyamanan Lingkungan}

Kenyamanan lingkungan, yang berkenaan dengan lingkungan, kondisi dan pengaruh dari luar kepada manusia seperti temperatur, warna, pencahayaan, kebisingan, dan lain-lain dapat dilihat pada tabel 4 berikut.

Tabel 4. Faktor Kenyamanan Lingkungan

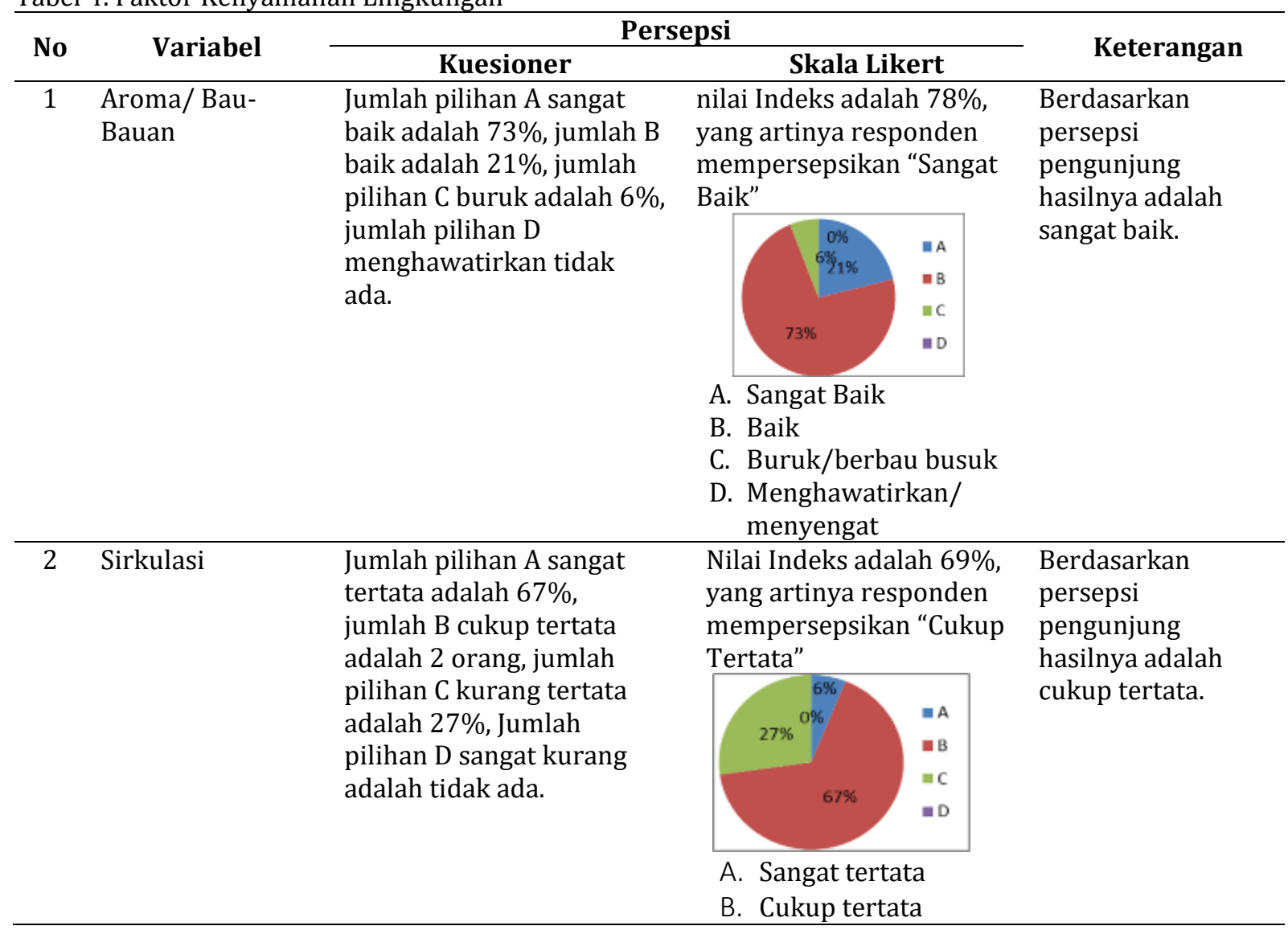


Ibrahim Tuahena

Triyatni Martosenjoyo

Abdul Mufti Radja

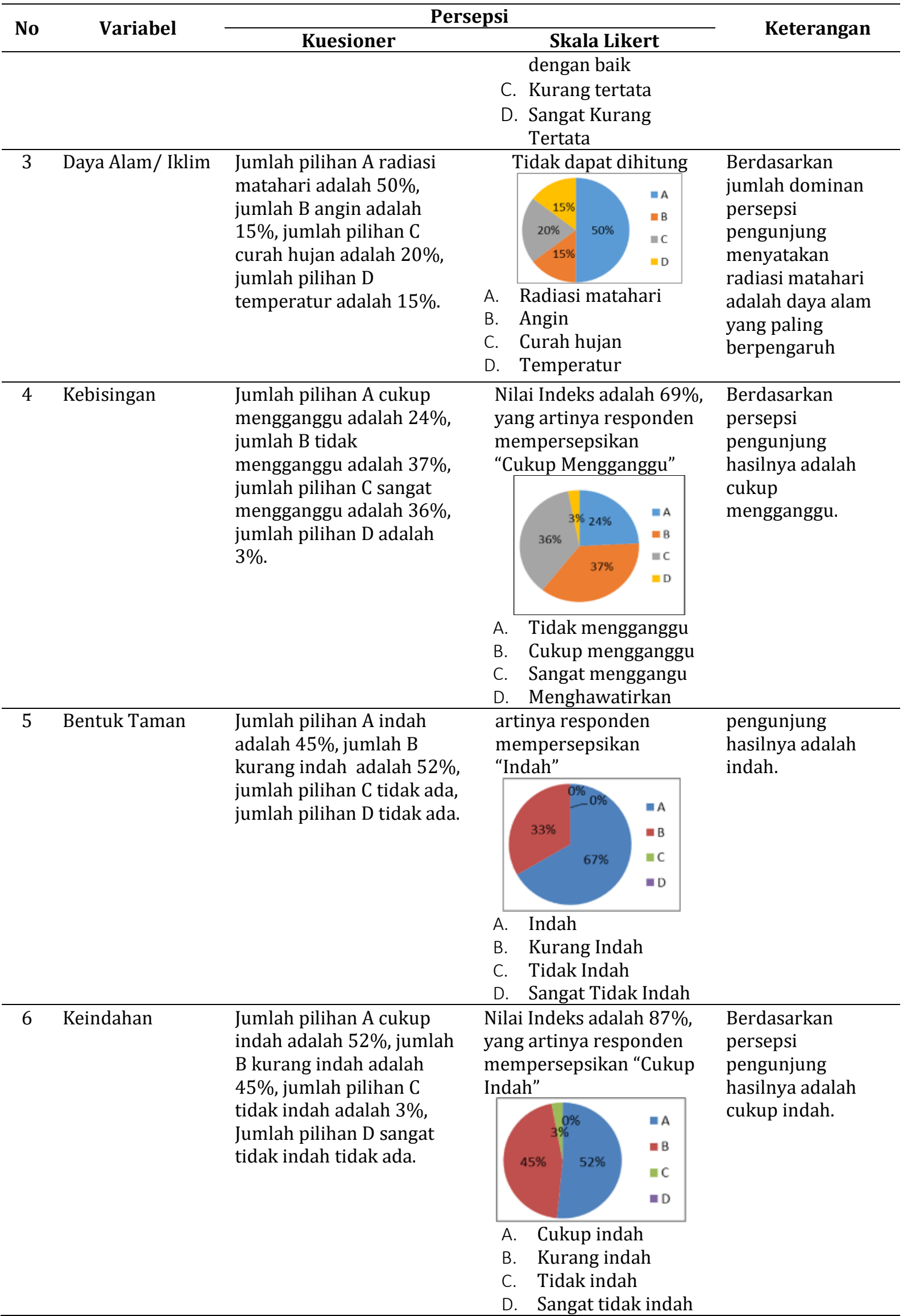


Ibrahim Tuahena*, Triyatni Martosenjoyo, Abdul Mufti Radja

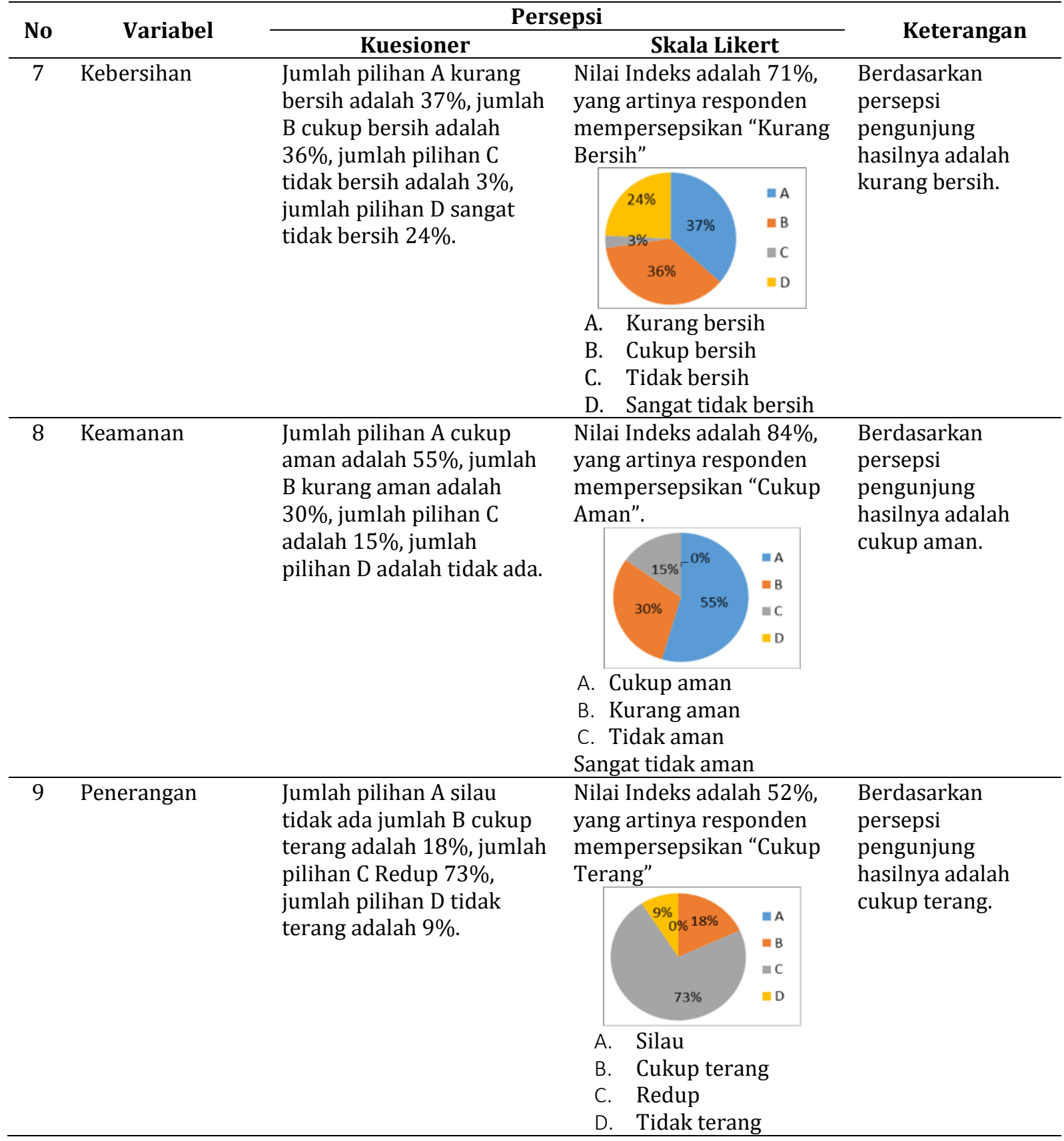

Sumber. Analisis Peneliti

Tabel 4 menunjukan bahwa hasil persepsi dari responden mengenai faktor kenyamanan lingkungan pada terbuka publik Fort Rotterdam memberi simpulan bahwa faktor yang masuk dalam kategori sangat baik adalah aroma/baua-bauan, faktor yang dalam kategori baik adalah sirkulasi, bentuk, keindahan, keamanan dan penerangan, sedangkan faktor yang dalam kategori tidak baik adalah kebersihan dan kebisingan kawasan. Kesimpulan dari seluruh faktor kenyamanan yang berpengaruh (fisik, psikospiritual, sosiokultural, dan lingkungan) yakni faktor kenyamanan fisik yang masih kurang baik karena berdasarkan antropometri pada fasilitas dominan tidak sesuai standar. Faktor kenyamanan Psikospiritual pada kawasan belum bisa terpenuhi dengan baik sebab walaupun kondisi tanaman/pohon sudah baik namun kondisi keberadaan air pada lokasi ini terkesan tidak terawat, kawasan ini juga belum sepenuhnya terhindar dari kebisingan. 
Ibrahim Tuahena

Triyatni Martosenjoyo

Abdul Mufti Radja

Faktor kenyaman sosial sudah baik pada kawasan ruang publik ini karena sering terlihat interaksi sosial masyarakat umum maupun dalam sebuah komunitas masyarakat, hal ini berarti kawasan ini memberi ruang yang nyaman untuk interaksi sosial masyarakat. Selanjutnya faktor kenyamanan lingkungan sudah baik karena berdasarkan indikator kenyamanan menurut Rustam (2012) dominan dalam kondisi baik.

\section{KESIMPULAN}

Persepsi pengunjung terhadap kenyaman fasilitas ruang terbuka publik Fort Rotterdam. Fasilitas pada ruang terbuka publik ini sudah nyaman karena dominan pengunjung mempersepsikan baik, yakni paving 67\%, tanaman peneduh $63 \%$, kios, shelter/kanopi $60 \%$, tempat sampah $57 \%$, lampu $63 \%$, dan penanda $50 \%$, sedangkan untuk bangku $47 \%$ artinya hanya fasilitas ini yang dipersepsikan kurang baik. Faktor-faktor yang mempengaruhi persepsi pengunjung terhadap kenyamanan fasilitas ruang publik Fort Rotterdam yang telah dikelompokan berdasarkan variabel kenyamanan (fisik, psikospiritual, sosiokultural, dan lingkungan) dianalisis berdasarkan persepsi, standar teori dan peraturan yang diterbitkan pemerintah yang telah dipaparkan dalam pembahasan dan hasilnya adalah faktor kenyamanan fisik belum baik, kenyamanan psikospiritual belum baik, kenyamanan sosiokultural sudah baik dan kenyamanan lingkungan yang juga baik.

\section{DAFTAR REFERENSI}

Hildayanti, A, dan Wasilah. 2017. "Karakteristik Benteng Fort Rotterdam sebagai Urban Artefact Kota Makassar.” In , 019-026. Seminar Heritage IPLBI.

"Peraturan Menteri Pekerjaan Umum NO: 03/PRT/M/2014." n.d.

Rustam, Hakim. 2012. Komponen Perancangan Arsitektur Lansekap. 2 ed. Jakarta: Bumi Aksara.

Santosa, Muhammad Ardli, Rasdyana, Ahmad Syauki, dan Lexsi Yosua Masseleng. 2018.

"Kualitas Perancangan Taman Benteng Roterdam Makassar." Nature : National Academic Journal of Architecture 5 (1): 59-61. https://doi.org/10.24252/nature.v5i1a6.

Whyte, H. W. 1980. The Social Life Of Small Urban Spaces. New York: Project for Publik Spaces.

Wiharnanto, S. 2006. "Pengaruh Disain Arsitektur Elemen-Elemen Ruang Publik Terhadap Kunjungan Pengguna Kawasan.” Program Studi Magister Teknik Arsitektur Universitas Diponegoro. Semarang.

Wijayaningsih, R. 2007. "Keterkaitan Pedagang Kaki Lima Terhadap Kualitas Dan Citra Ruang Publik Di Koridor Kartini Semarang Pada Masa Pra-Pembongkaran.” Program Pascasarjana Program Studi Magister Teknik Arsitektur Universitas Diponegoro. Semarang. 